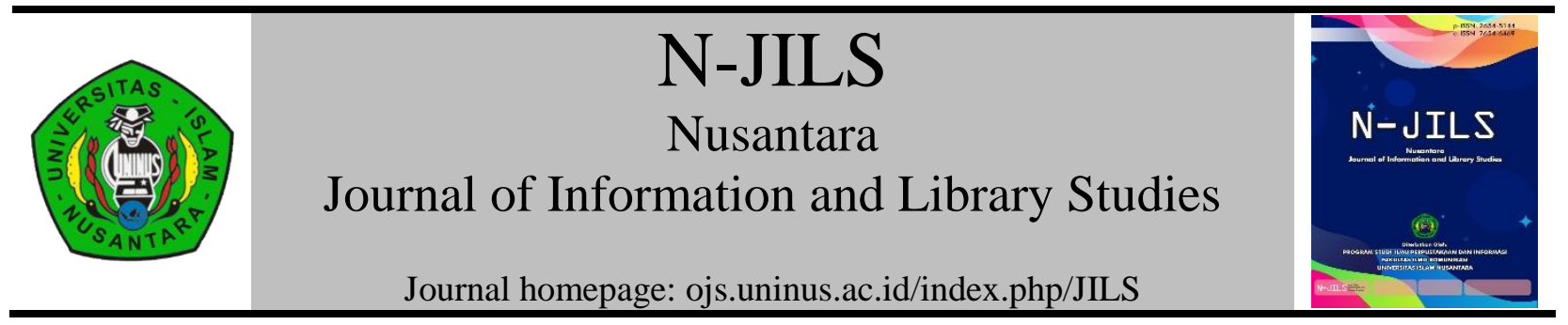

\title{
Transfer Pengetahuan Di Perpustakaan Kementerian Hukum Dan Hak Asasi Manusia Republik Indonesia
}

\section{Knowledge Transfer In Kementerian Hukum Dan Hak Asasi Manusia Republik Indonesia Library}

\author{
Bumi Achmad Ragili' ${ }^{1}$, Yunus Winoto ${ }^{2}$, Andri Yanto ${ }^{3}$ \\ ${ }^{123}$ Program Studi Perpustakaan \& Sains Informasi, Universitas Padjadjaran \\ e-mail: ${ }^{1}$ bumiragil@mail.unpad.ac.id, ${ }^{2}$ yunus.winoto@unpad.ac.id, ${ }^{3}$ andri.yanto@unpad.ac.id
}

\begin{tabular}{ll}
\hline ARTICLE INFO & ABSTRACT \\
\hline Article history & This paper aims to know how the knowledge transfer \\
Received [May 2020] & process runs in the Library of Ministry of Law and Human \\
Revised [June 2020] & Rights. The method used in this paper is qualitative \\
Accepted [June 2020] & research were taken through interviews, observation and \\
Available Online [June 2020] & documentation studies. A case study approach is used on \\
this paper by seeing reality from librarian activites. The & results of this paper indicate that socialization in the \\
Kemenkumham Library occurs through discussion of \\
librarians and the leaders. Externalization is carried out \\
through librarian activities which are poured into new \\
forms. Combination is done by collecting, transferring or \\
disseminating, and processing information and knowledge \\
obtained from the externalization stage into the annual \\
report. Internalization has not yet been optimized because \\
librarians are still focusing on library processing activities. \\
Moreover, the report documents can become new \\
knowledges for librarians and organizations. The existing \\
obstacles in knowledge transfer process in Kemenkumham \\
Library are in human resources and the budget for library \\
activities such as holding workshops and training activities \\
that can be a media for library promotion. Knowledge \\
Transfer in the Library of the Ministry of Law and Human \\
Rights are carried out through a process of socialization, \\
externalization, combination, and internalization.
\end{tabular}


Keyword: Knowledge Management; Knowledge Transfer; Employee, Kemenkumham

Kata kunci: managemen pengetahuan; transfer pengetahuan; pegawai, Kemenkunham

\begin{abstract}
ABSTRAK
Penelitian ini bertujuan untuk mengetahui bagaimana proses transfer pengetahuan yang ada di Perpustakaan Kementerian Hukum dan Hak Asasi Manusia. Metode yang digunakan dalam penelitian ini adalah kualitatif yang diperoleh dari hasil wawancara, observasi, dan studi dokumentasi. Pendekatan studi kasus yang digunakan dalam penelitian ini adalah untuk melihat kejadian sebenarnya dari aktivitas pustakawan. Hasil dari penelitian ini menunjukan bahwa proses sosialisasi di Perpustakaan Kemenkumham terjadi melalui diskusi pustakawan dan pimpinan. Proses eksternalisasi dilakukan melalui kegiatan pustakawan yang dituangkan ke dalam bentuk baru. Proses kombinasi dilakukan dengan mengumpulkan, mentransfer atau menyebarkan, dan mengolah informasi maupun pengetahuan yang diperoleh dari tahap eksternalisasi ke dalam laporan tahunan. Proses internalisasi di Perpustakaan Kemenkumham belum optimal dilakukan dikarenakan pustakawan masih berfokus pada kegiatan pengolahan perpustakaan. Namun dalam hal ini, dokumen laporan tersebut dapat menjadi pengetahuan baru bagi pustakawan maupun organisasi. Hambatan yang ada di Perpustakaan Kementerian Hukum dan Hak Asasi Manusia yaitu pada sumber daya manusia dan anggaran untuk kegiatan perpustakaan seperti workshop maupun pelatihan yang dapat menjadi media promosi perpustakaan. Transfer pengetahuan di Perpustakaan Kementerian Hukum dan Hak Asasi Manusia dilakukan melalui sosialisasi, eksternalisasi, kombinasi, dan internalisasi.
\end{abstract}

(C) 2020 NJILS. All rights reserved.

\section{A. PENDAHULUAN}

Perpustakaan Kementerian Hukum dan Hak Asasi Manusia Republik Indonesia merupakan salah satu jenis perpustakaan khusus. Perpustakaan ini termasuk ke dalam perpustakaan khusus karena berada di bawah Kementerian Hukum dan Hak Asasi Manusia Republik Indonesia. Perpustakaan ini berdiri pada tahun 2005, yang sebagian besar koleksi berasal dari buku dengan subjek hukum dan undang-undang mengenai hak asasi manusia (HAM)

yang ada dan berlaku di indonesia yang diterbitkan oleh Kementerian Hukum dan Hak Asasi Manusia Republik Indonesia sendiri maupun dari lembaga lainnya dan terdapat koleksi referensi lainnya. 
Perpustakaan Kementerian Hukum dan Hak Asasi Manusia Republik Indonesia merupakan perpustakaan di Jalan H.R Rasuna Said No.Kav 6-7 daerah Karet Kuningan, Kota Jakarta Selatan. Suatu perpustakaan tentunya terdapat tenaga ahli atau staf untuk mengelola perpustakaan. Tenaga ahli atau staf tersebut merupakan karyawan atau pustakawan di Perpustakaan Kementerian Hukum dan Hak Asasi Manusia Republik Indonesia. Undang-Undang Republik Indonesia Nomor 43 Tahun 2007 tentang perpustakaan menjelaskan bahwa pustakawan adalah seseorang yang berkompeten pada bidangnya di mana hal tersebut diperoleh melalui pendidikan dan/atau pelatihan kepustakawanan serta mempunyai tugas dan tanggung jawab untuk melaksanakan pengelolaan dan pelayanan perpustakaan. Berbagai aktivitas maupun rutinitas di perpustakaan juga terjadi mulai dari interaksi antar karyawan maupun antara karyawan dengan pimpinan seperti disaat adanya aktivitas maupun melalui diskusi seperti rapat atau sesi tanya jawab yang dilakukan oleh para karyawan yang bersifat teknis atau nonteknis maupun dalam melakukan rutinitas-rutinitas kepustakawanan lainnya.

Salah satu aktivitas yang dapat dilakukan oleh pustakawan atau karyawan adalah berbagi pengetahuan melalui transfer pengetahuan antara satu sama lain. (Chen, Chu, \& Xu, 2012) mengatakan ada empat kategori proses perpindahan pengetahuan di antaranya, berbagi pengetahuan antara pustakawan dengan pengguna untuk saling berbagi sumber informasi, penyebaran informasi melalui berita dan pengumuman yang diperbaharui (update) dari perpustakaan, komunikasi yang ditujukan ke individual, dan percakapan antar pustakawan dan pemustaka atau antar pemustaka. Sumber daya seperti pengetahuan (knowledge) sangat erat hubungannya dengan sumber daya manusia yang merupakan aset dan modal intelektual dalam organisasi (Parindra, 2018). Pengetahuan dapat dilakukan melalui transfer pengetahuan (knowledge transfer), sebagai proses belajar suatu unit organisasi (individu, kelompok, departemen, atau divisi) berdasarkan pengalaman dari unit organisasi lain. Pada tingkat individu, transfer pengetahuan memiliki makna sebagai sebuah proses duplikasi pengetahuan dari sumber pengetahuan ke penerima (Indriartiningtias \& Mafrufah, 2012). Adapun fokus utama dari dari knowledge transfer dari masing-masing individu yaitu mampu menjelaskan, mengkodekan dan mengkomunikasikan pengetahuan kepada orang lain, kelompok, dan khususnya kepada organisasi. Knowledge transfer dapat terjadi diantara individu, di dalam dan diantara tim, antara unit organisasi, dan antara organisasi (Glassop, 2002). 
Fenomena penelitian ini mengenai transfer pengetahuan yang terjadi di Perpustakaan Kementerian Hukum dan Hak Asasi Manusia Republik Indonesia. Para pustakawan melakukan transfer pengetahuan pada pemustaka dan sesama pustakawan, melalui kegiatan berbagi pengetahuan antara pustakawan dengan pengguna untuk saling berbagi sumber informasi, penyebaran informasi melalui berita dan pengumuman yang diperbaharui (update) dari perpustakaan, komunikasi yang ditujukan ke individual, dan percakapan antar pustakawan dan pemustaka atau antar pemustaka. Pustakawan menjadi pusat sentral dalam menyebarkan pengetahuan di lingkungan perpustakaan. Berdasarkan hal ini, fenomena ini menarik diteliti lebih mendalam. Mengapa pustakawan di Perpustakaan Kementerian Hukum dan Hak Asasi Manusia Republik Indonesia melakukan transfer pengetahuan? dan bagaimana praktik transfer pengetahuan yang terjadi di Perpustakaan Kementerian Hukum dan Hak Asasi Manusia Republik Indonesia.

Adanya kesadaran yang tumbuh dalam diri karyawan maupun pustakawan akan pentingnya informasi dan membagikannya kepada orang lain serta memajukan perpustakaannya menjadi salah satu alasan tejadinya transfer pengetahuan. Hal itu juga terkait dengan tugasnya sebagai karyawan atau pustakawan dalam perannya sebagai pengelola informasi. Kesadaran pustakawan akan tugasnya sebagai pengelola informasi dan didukung dengan interaksi yang baik di lingkungan antar rekan kerja, antar karyawan atau pustakawan, dan karyawan dengan atasan akan membentuk budaya sharing di lingkungan tersebut. Berdasarkan uraian latar belakang tersebut, maka rumusan masalah dalam penelitian ini yaitu bagaimana transfer pengetahuan yang terjadi antar karyawan di Perpustakaan Kemenkumham Republik Indonesia. Tujuan penelitian ini untuk mengetahui proses dan hambatan yang terjadi dalam transfer pengetahuan yang terjadi di Perpustakaan Kemenkumham. Originalitas dari penelitian ini terletak pada pengungkapan mengenai kegiatan transfer pengetahuan yang ada di Perpustakaan Kemenkumham.

\section{B. TINJAUAN PUSTAKA}

Pengetahuan merupakan suatu yang tidak berwujud namun dapat dikonversikan ataupun diformulasikan sedemikian rupa sehingga pengetahuan tersebut memiliki wujud tercetak. Pengetahuan tacit dan explicit tidak bisa dipisahkan satu sama lain, mereka saling melengkapi dan berinteraksi dalam lingkungan hubungan antar manusia yang disebut dengan proses transfer pengetahuan. Menurut Nonaka dan Takeuchi (1995) proses transfer pengetahuan ini terdiri atas 
empat tahap. Pertama, socialization (Sosialisasi), merupakan transfer pengetahuan tacit di antara individu melalui observasi, peniruan, persepsi komunikasi, dan praktik. Kedua, externalization (eksternalisasi), merupakan jenis pengetahuan yang dipicu oleh dialog atau refleksi kolektif dan sering lahir atas dasar analogi dan metafor yang menerjemahkan pengetahuan tacit ke dalam prosedur dan dokumen, termasuk melalui proses komunikasi bermedia. Ketiga, combination (kombinasi), merupakan rekonfigurasi pengetahuan explicit, dengan cara menyortir, mengklasifikasikan, dan mengembangkan semuanya melalui organisasi. Keempat, internalization (internalisasi), merupakan proses menerjemahkan pengetahuan explicit ke dalam pengetahuan tacit secara individual, contohnya dari konversi yang terakhir ini adalah penerapan melalui pengamatan, membaca dokumen, dan olah pikir untuk pembelajaran.

Transfer pengetahuan merupakan salah satu upaya mengkomunikasikan atau menyampaikan maupun memindahkan pengetahuan antar individu ataupun kepada individu lainnya. Transfer pengetahuan adalah tahap diseminasi dan penyediaan pengetahuan pada saat yang tepat untuk karyawan yang membutuhkan (Tobing 2007, 9). Transfer pengetahuan juga dapat didefinisikan sebagai aktivitas mentransfer atau menyebarkan pengetahuan dari seseorang, grup atau organisasi ke individu, grup atau organisasi yang lain (Lee, 2005).

Kajian literatur mengenai transfer pengetahuan di Perpustakaan masih sangat jarang. Namun beberapa penelitian mengenai knowledge sharing di perpustakaan lainnya telah banyak dilakukan. Penelitian sebelumnya terkait knowledge sharing di perpustakaan diantaranya (Syam, 2017; Nurbaiti, 2013). Pada dasarnya, transfer pengetahuan merupakan salah satu upaya mengkomunikasikan atau menyampaikan maupun memindahkan pengetahuan antar individu ataupun kepada individu lainnya. (Lee, 2005) mendefinisikan transfer pengetahuan sebagai aktivitas mentransfer atau menyebarkan pengetahuan dari seseorang, grup, atau organisasi ke individu, atau organisasi yang lain.

Lebih lanjut Rodin (2015) menambahkan penjelasannya mengenai indikator dapat terlaksananya berbagi pengetahuan adalah sebagai berikut. Pertama, terjadinya dan terbentuknya teamwork dalam sebuah permasalahan dan diskusi serta tercipta budaya kerja yang tepat. Kedua, melakoni proses learning by doing, sharing atau diskusi akan terbentuk dengan keadaan yang ada yang menuntut untuk saling berbagi pengetahuan. Ketiga, adanya rasa bersaing dan berkompetisi antar instansi untuk dapat mewujudkan instansi yang menyediakan berbagai 
informasi dengan penerapan knowledge sharing. Keempat, kecepatan dan kelambatan penerimaan dan penyampaian knowledge dapat menjadi penghambat dan pendorong proses knowledge sharing.

Suatu organisasi biasanya memiliki sistem tersendiri yang dianut oleh anggotanya yang membedakan suatu organisasi dengan organisasi lainnya. Dalam organisasi tentunya memiliki suatu cara hidup yang dimiliki bersama oleh organisasi atau komunitas dan diwariskan secara turun temurun. Budaya berbagi dalam sebuah organisasi terdiri dari beberapa hal (Tobing, 2007), di antaranya peranan kepemimpinan merumuskan visi, keterlibatan langsung dalam pemberian dukungan dan motivasi, budaya organisasi yang memberikan iklim kepercayaan dan keterbukaan, adanya kemauan dari pimpinan organisasi untuk mempromosikan knowledge sharing dan kolaborasi, organisasi menghargai knowledge, pembelajaran dan inovasi, organisasi memiliki struktur yang adaptif, dan adanya kemampuan organisasi dalam mengeksekusi proses transformasi dengan mulus dan efektif.

Berdasarkan pemaparan tersebut, dapat dikatakan bahwa transfer pengetahuan dan budayanya merupakan sebuah kegiatan interaksi antar individu atau antar kelompok (team work) dalam bentuk komunikasi atau semacamnya dengan tujuan untuk peningkatan dan pengembangan diri setiap anggota atau individu sebagai upaya organisasi dalam memberikan motivasi, menciptakan iklim kepercayaan dalam organisasi, melakukan diskusi dalam upaya pembelajaran dan pengembangan diri tiap anggotanya.

Aktivitas transfer pengetahuan mencakup dua tindakan yakni penyampaian atau pengiriman pesan (transmisi) dan penyerapan atau penerimaan pesan (absorsi) oleh seseorang atau kelompok di dalam organisasi (Sangkala, 2007). Oleh karena itu, hambatan terbesar di dalam upaya organisasi melakukan transfer pengetahuan adalah keputusan penerima untuk menolak atau menerima pengetahuan baru dari sumber (Indriartiningtias \& Mafrufah, 2012). Pertentangan akan menghambat bahkan mencegah berlangsungnya proses transfer pengetahuan dan kemungkinan mengikis pengetahuan yang ada.

\section{METODE PENELITIAN}

Metode penelitian yang digunakan adalah metode penelitian kualitatif yang secara bertahap dimulai dengan penentuan topik, pengumpulan data, dan menganalisis data sehingga nantinya diperoleh suatu pemahaman dan pengertian atas topik atau isu tertenu. Menurut 
(Sugiyono, 2015) metode penelitian kualitatif adalah metode penelitian yang digunakan untuk meneliti pada kondisi objek yang alamiah, dimana peneliti adalah sebagai instrumen kunci, teknik pengumpulan data dilakukan dengan triangulasi, analisis data bersifat induktif, dan hasil penelitian kualitatif menekankan makna dari pada generalisasi. Dalam penelitian ini pendekatan yang digunakan adalah studi kasus. Penelitian dengan pendekatan studi kasus merupakan strategi yang lebih cocok dilakukan dengan menjawab pertanyaan how dan why (Yin, 2014). Lebih lanjut, studi kasus dapat diartikan sebagai serangkaian kegiatan ilmiah yang dilakukan secara intensif, terinci, dan mendalam tentang suatu program, peristiwa, dan aktivitas baik pada tingkat perorangan, sekelompok orang, lembaga atau organisasi untuk memperoleh pengetahuan mendalam tentang peristiwa tersebut (Rahardjo, 2017).

Peneliti memilih menggunakan pendekatan studi kasus karena pendekatan studi kasus digunakan untuk melihat realitas dari perspektif berupa kegiatan yang ada dalam suatu unit analisis tersebut. Pemilihan informan dalam penelitian ini menggunakan purposive sampling dengan kriteria: merupakan karyawan Perpustakaan Kemenkumham, terlibat dalam kegiatan kepustakawanan, dan terlibat dalam proses transfer pengetahuan. Teknik pengumpulan data yang digunakan oleh penulis diantaranya observasi, wawancara, dan studi dokumentasi. Ketiga teknik tersebut digunakan untuk melengkapi yang lainnya. Adapun teknik analisis data yang dilakukan melalui pengumpulan data, pemilihan data, cek keabsahan data, dan penyimpulan. Peneliti mengumpulkan data hasil observasi, wawancara dan literatur. Lalu peneliti memilih data yang sesuai pertanyaan penelitian untuk digunakan sebagai kutipan wawancara. Selain itu, peneliti melalukan cek keabsahan data, di mana data yang dipilih dianalisis kemudian disimpulkan.

\section{HASIL DAN PEMBAHASAN}

Pustakawan di Perpustakaan Kementerian Hukum dan Hak Asasi Manusia Republik Indonesia melakukan kegiatan transfer pengetahuan pada pemustaka dan sesame pustakawan. Transfer pengetahuan yang dilakukan terdiri dari kegiatan sosialisasi (socialization),, eksternalisasi (externalization), kombinasi (combination), dan internalisasi (internalization). Proses sosialisasi (socialization) merupakan tahap awal dalam transfer pengetahuan. Proses sosialisasi merupakan proses menyampaikan pengetahuan tacit yang dimiliki oleh seseorang kepada individu lainnya melalui komunikasi. Hal ini dapat terjadi dari aktivitas di dalam suatu lingkungan tersebut maupun dari aktivitas di luar lingkungan maupun lembaga tersebut yang 
dapat mendukung untuk terjadinya transfer pengetahuan. Sehingga Informan sebagai pustakawan di Perpustakaan Kementerian Hukum dan Hak Asasi Manusia Republik Indonesia memaparkan mengenai interaksi yang dilakukan antar pustakawan sebagai berikut:

"Interaksinya berupa saling sharing untuk pekerjaan, sharingnya itu sendiri diantaranya dalam kegiatan pengolahan seperti entri data, sirkulasi, dan pembuatan tajuk subjek juga. [...] mau nggak mau kita harus saling sharing agar kendala yang terdapat dalam pekerjaan bisa teratasi" (Anonim, wawancara, October 30, 2018)

Selain interaksi antar pustakawan, tentunya seorang pustakawan berkoordinasi dengan pimpinannya dalam setiap kegiatan atau informasi yang dianggap penting untuk perpustakaan itu sendiri dan kemajuan perpustakaan tersebut. Informan mencoba menggambarkan interaksi yang terdapat di Perpustakaan Kementerian Hukum dan Hak Asasi Manusia Republik Indonesia sebagai berikut.

“[...] kita berusaha untuk membangun komunikasi yang lancar, jadi apa yang menjadi kendala di perpustakaan tidak perlu ragu-ragu kalau perlu disampaikan ya sampaikan saja, nanti kalau infonya sudah sampai ke saya, kalau nantinya perlu untuk ambil sikap ya kita ambil sikap, kalau memang tidak, mesti ke pimpinan yang lebih tinggi lagi ya saya akan komunikasikan ke pimpinan yang lebih tinggi lagi. Jadi artinya, tidak ada kendal" (Anonim, wawancara, November 1, 2018).

Seorang pustakawan juga tentunya bersinggungan dengan pengguna atau pemustaka. Interaksi tersebut dapat terjadi ketika seorang pengguna atau pemustaka membutuhkan suatu bahan pustaka atau referensi tertentu namun mengalami kendala di dalam proses pencariannya. Hal tersebut dilakukan pustakawan dengan memberi arahan kepada pemustaka agar pemustaka dapat menemukan bahan pustaka yang dibutuhkan namun tetap membiarkan keleluasaan para pemustaka tersebut untuk mandiri dalam menemukan dimana bahan pustaka tersebut disimpan. Menyampaikan informasi tidak hanya melalui arahan atau intruksi tertentu, menyampaikan pendapat atau gagasan juga dapat termasuk dalam bentuk menyampaikan informasi. Untuk menyampaikan aspirasi atau gagasan tersebut tentunya membutuhkan suatu wadah yang dapat menampung aspirasi tersebut melalui media pertemuan atau diskusi seperti rapat.

Selain melalui diskusi ataupun interaksi langsung antar pustakawan maupun antara pustakawan dengan pimpinan, pustakawan dan pimpinan juga mempunyai media komunikasi grup melalui whatsapp, hanya saja grup tersebut belum terdapat aktivitas di dalamnya. Hal 
tersebut disebabkan karena grup dimana terdapat pustakawan maupun pimpinan tersebut baru saja dibuat. Hal ini disampaikan oleh Informan sebagai berikut.

“Grup internal perpustakaan itu grupnya gabung sama kepala dan staf lain, bukan khusus pustakawan,bisa dibilang grup sub perpustakaan. Isinya itu staf dan kepala disub perpustakaan" (Anonim, October 31, 2018).

Proses sosialisasi ini meliputi sharing dalam kegiatan sehari-hari diantaranya dalam hal pengolahan bahan pustaka. Hal ini dilakukan untuk mencegah dan mengatasi kemungkinan kendala yang ada. Sehingga dengan adanya kegiatan sharing selama proses kerja berlangsung, terdapat pertukaran maupun perpindahan pengetahuan didalamnya. Terkait pertemuan atau diskusi, hal tersebut tidak dilakukan secara rutin dalam setiap bulan, melainkan pertemuan dan diskusi tersebut diadakan berdasarkan kebutuhan atau jika akan diadakan agenda atau acara tertentu seperti seminar, workshop dan lain-lain. Selanjutnya hasil dari seminar tersebut nantinya disampaikan kepimpinan guna menyebarkan pengetahuan yang didapat dari luar organisasi.

Proses eksternalisasi (externalization) merupakan tahap selanjutnya dalam transfer pengetahuan. Proses eksternalisasi merupakan proses merubah bentuk atau menuangkan pengetahuan tacit yang dimiliki oleh seseorang ke dalam bentuk pengetahuan explicit. Dalam hal ini, proses eksternalisasi yang terjadi di Perpustakaan Kemenkumham seperti yang dipaparkan Informan adalah sebagai berikut:

"Ada yang pernah menulis, saya juga pernah menulis, topiknya tentang perpustakaan, tapi itu tidak rutin, tergantung situasi dan kondisinya, nulisnya ke dalam bentuk makalah biasanya paling banyak, ke jurnalnya hanya sekali atau dua kali kalau tidak salah, topik atau temanya sendiri tentang data dan informasi, selain itu juga kita membuat banner perpustakaan dimana isinya seputar Perpustakaan. Selain itu, juga saya dulu pada tahun 2013 juga pernah membuat artikel, dan artikel itu sempat dikirim juga dalam forum seperti simposium pada saat saya masih sekolah dulu" (Anonim, wawancara, October 31, 2018).

Dalam diskusi yang dilakukan antar pustakawan maupun antara pustakawan dengan pimpinan di Perpustakaan Kementerian Hukum dan HAM tidak menghasilkan atau membuat suatu catatan atau notulensi dikarenakan sifat dari diskusi tersebut yang lebih sering melakukan diskusi informal. Hal ini juga disampaikan oleh Informan dalam pernyataannya sebagai berikut:

"Karena tadi saya bilang kita lebih seringnya diskusi informal, jadi ya setelah diskusi paling buah pikir saja yang kita bawa, tidak ada yang tertulis" (Anonim, wawancara, October 31, 2018). 
Hanya saja, di dalam diskusi informal tersebut tidak menghasilkan notulensi, melainkan informasi-informasi yang diperoleh dan disampaikan hanya buah pikir yang dihasilkan dari diskusi tersebut. Hal ini dikarenakan sifat dari penyampaian informasi tersebut yang disampaikan melalui diskusi informal. Sehingga dari diskusi tersebut, informasi yang disampaikan, kemudian ditangkap ataupun dipahami oleh peserta diskusi bersifat tacit.

Proses kombinasi (combination) merupakan tahap ketiga dalam transfer pengetahuan. Proses kombinasi merupakan proses menerapkan berbagai pengetahuan explicit untuk disusun dan diproses ke dalam sistem pengetahuan tertentu. Pengetahuan yang diperoleh dari tahap eksternalisasi kemudian diolah dengan kelompok tertentu dalam organisasi. Sehingga, proses mengumpulkan dan mengintegrasikan informasi ataupun pengetahuan yang ada di Perpustakaan Kemenkumham dilakukan melalui kegiatan seperti yang dijelaskan menurut Informan yakni sebagai berikut:

"Seperti yang sudah saya bilang sebelumnya, dari setiap kegiatan kita seperti seminar atau rapat atau semacamnya itu kita selalu bikin laporannya. Karena kan itu yang nantinya disampaikan ke pimpinan. Informasi yang didapat itu nantinya diolah dalam bentuk laporan" (Anonim, wawancara, October 31, 2018).

Selanjutnya dalam proses kombinasi adalah mentransfer atau menyebarkan pengetahuan yang didapat tersebut. Bentuk pentransferan dan penyebaran informasi ataupun pengetahuan yang didapat melalui kegiatan yang diikuti oleh pustakawan dilakukan dengan mengirim laporan tersebut kepada Kasubag dan pimpinan lalu disampaikan kembali melalui diskusi. Seperti yang sudah dijelaskan sebelumnya, informasi dan pengetahuan yang sudah didapat dari kegiatan tersebut dituangkan kembali melalui bentuk laporan dan disampaikan kembali dalam diskusi. Bentuk laporan kegiatan tersebut selanjutnya mengalami proses pengeditan menjadi bentuk seperti yang dijelaskan menurut Informan sebagai berikut:

"Dari laporan-laporan kegiatan yang kita ikuti itu kan kita bikin laporannya, dari sekian banyak laporan-laporan itu ketika akhir tahun kita kompilasi dalam laporan tahunan" (Anonim, wawancara, October 31, 2018).

Terdapat proses mengumpulkan dan mengkompilasi laporan-laporan yang sebelumnya telah dibuat, diolah oleh pustakawan dan diedit kembali sedemikian rupa ke dalam bentuk laporan tahunan. Sehingga dari sekian banyak informasi ataupun pengetahuan yang didapat dari kegiatan tersebut dapat diorganisasikan dengan baik melalui bentuk tersebut. Proses kombinasi yang ada di Perpustakaan Kementerian Hukum dan HAM dilakukan dengan mengumpulkan atau 
menghimpun informasi dari kegiatan seminar maupun rapat di dalam ataupun di luar organisasi, menyebarkan informasi maupun pengetahuan tersebut dalam bentuk file maupun melalui diskusi, dan diolah atau diedit kembali ke dalam bentuk laporan tahunan.

Sedangkan pada proses internalisasi (internalization) merupakan tahap terakhir dalam transfer pengetahuan. Proses internalisasi merupakan proses mengubah ataupun menciptakan bentuk pengetahuan dari pengetahuan explicit ke dalam bentuk pengetahuan tacit. Dalam hal ini, pengetahuan explicit mengalami proses konversi atau perubahan dari pengetahuan itu sendiri ke dalam bentuk lain atau media lain. Proses internalisasi juga merupakan proses penciptaan dalam mempelajari dan mengumpulkan pengetahuan baru. Proses internalisasi dapat terjadi melalui sebuah kegiatan diantaranya seperti pelatihan atau workshop. Namun, dalam hal ini, pustakawan di Perpustakaan Kementerian Hukum dan HAM belum melakukan atau mengadakan pelatihan melainkan hanya mengikuti pelatihan. Hal tersebut dikarenakan pekerjaan para pustakawan yang masih berfokus pada pengolahan bahan pustaka. Hal ini dijelaskan melalui hasil wawancara dengan Informan seperti yang dipaparkan dibawah ini.

"Jadi gini, perpustakaan disini lebih ke koleksi buku, jadi masih seperti itu, menyimpan koleksi ke katalog online. Tapi kalau untuk kegiatan yang beragam itu kita belum melakukan itu, karena kita sekarang fokusnya juga masih klasifikasi, jadi memang karena keterbatasan sdm jadi tidak banyak melakukan kegiatan tersebut atau bahkan tidak ada" (Anonim, wawancara, October 31, 2018).

Selain pernyataan tersebut, Informan juga menambahkan mengenai pelatihan yang diikuti dalam pernyataannya sebagai berikut.

"Ya saya pernah ikut pelatihan perpustakaan [...] Tapi kalo disini penyebaran informasinya belum lancar, karena seperti yang saya bilang sebelumnya kita masih repot mengurus teknis pengolahan, jadi yang kita sampaikan itu hanya laporannya aja" (Anonim, wawancara, October 31, 2018).

Berdasarkan hasil penelitian yang telah diperoleh, proses internalisasi belum dilakukan di Perpustakaan Kementerian Hukum dan HAM. Hal tersebut dikarenakan pustakawan masih berfokus pada kegiatan pengolahan perpustakaan. Namun dalam hal ini, pustakawan di Perpustakaan Kementerian Hukum dan HAM melakukannya dengan mengikuti pelatihanpelatihan dimana informasi maupun pengetahuan yang didapat tersebut diolah ke dalam bentuk laporan untuk disampaikan kepada pimpinan.

Dari hasil di lapangan, menyebutkan bahwa hambatan yang dirasakan oleh pustakawan di 
Perpustakaan Kementerian Hukum dan HAM terbagi menjadi beberapa hal diantaranya hambatan dalam proses penyampaian dan penerimaan informasi antar pustakawan, antara pustakawan dengan pimpinan dalam terlaksananya diskusi, hambatan mengenai kurangnya tenaga kerja, maupun hambatan terkait penyerapan anggaran yang ada di Perpustakaan Kementerian Hukum dan HAM. Sehingga dengan ketiga hambatan yang ada di Perpustakaan Kementerian Hukum dan HAM tersebut mempengaruhi kinerja dari pustakawan maupun kondisi didalam perpustakaan itu sendiri.

Sehingga, dari beberapa pemaparan yang telah dijelaskan tersebut, penulis mencoba merumuskan model transfer pengetahuannya menjadi sebagai berikut:

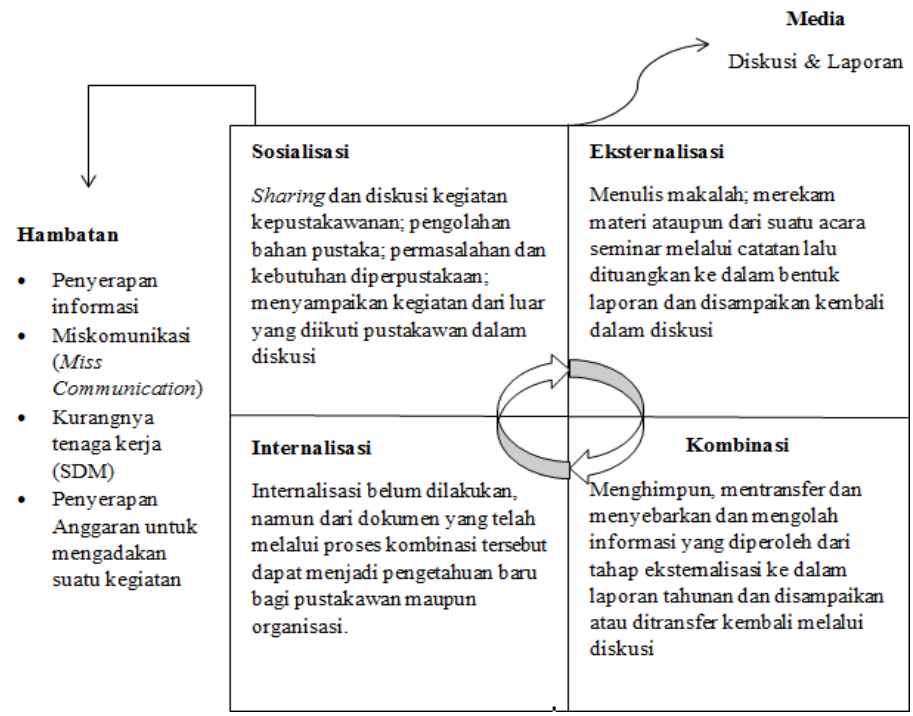

Gambar 3. Model Transfer Pengetahuan

Sumber: Hasil penelitian, 2019

Perpustakaan Kementerian Hukum dan Hak Asasi Manusia Republik Indonesia merupakan cara dalam menyampaikan atau menyebarkan pengetahuan yang didapat dari luar lembaga maupun mendiskusikan terkait perpustakaan guna mengembangkan perpustakaan dimana pustakawan tersebut berada. Transfer pengetahuan dalam hal ini terdiri dari empat proses diantaranya, sosialisasi, eksternalisasi, kombinasi dan internalisasi. Pada proses pertama, yaitu proses sosialisasi yang dilakukan di Perpustakaan Kemenkumham dilakukan dengan interaksi antar pustakawan, antara pustakawan dengan pimpinan, maupun antara pustakawan dengan pengguna melalui sharing formal maupun informal serta melalui arahan. Kegiatan sharing tersebut mendiskusikan mengenai permasalahan, kendala, maupun informasi yang didapat dari 
luar lembaga. Sehingga melalui interaksi tersebut, kendala atau permasalahan serta informasi yang didapat dari luar lembaga dapat menjadi bahan evaluasi untuk mengembangkan perpustakaan dalam pelayanan dan mencapai tujuan organisasi. Proses yang kedua, yaitu proses eksternalisasi yang dilakukan di Perpustakaan Kemenkumham dilakukan dengan menulis makalah dan merekam informasi yang diperoleh pustakawan dari informasi yang didapat di dalam lembaga maupun dari luar lembaga. Informasi yang diperoleh dari luar lembaga diantaranya melalui kegiatan-kegiatan seminar maupun rapat dari luar lembaga. Informasi tersebut nantinya dituangkan kembali ke dalam suatu bentuk laporan dan disampaikan kembali kepada pimpinan melalui diskusi. Sehingga dengan begitu, informasi yang didapat dari luar lembaga dapat menambah pengetahuan baru maupun inovasi baru bagi perpustakaan.

Proses yang ketiga, yaitu proses kombinasi yang dilakukan di Perpustakaan Kementerian Hukum dan Hak Asasi Manusia Republik Indonesia dilakukan dengan mengumpulkan, mentransfer atau menyebarkan, dan mengolah informasi yang diperoleh dari tahap eksternalisasi. Informasi maupun pengetahuan yang telah diolah dalam bentuk laporan pada proses eksternalisasi tersebut ditransfer maupun disebarkan kembali oleh pustakawan kepada pimpinan melalui laporan itu sendiri maupun melalui sebuah diskusi. Lebih lanjut dari proses tersebut, informasi maupun pengetahuan yang didapat dari kegiatan-kegiatan yang telah dituangkan ke dalam bentuk laporan tersebut dihimpun untuk diolah kembali ke dalam bentuk laporan tahunan. Proses yang terakhir yaitu, proses internalisasi belum dilakukan di Perpustakaan Kementerian Hukum dan Hak Asasi Manusia Republik Indonesia. Hal tersebut dikarenakan pustakawan masih berfokus pada kegiatan pengolahan perpustakaan. Namun dalam hal ini, pustakawan di Perpustakaan Kementerian Hukum dan Hak Asasi Manusia Republik Indonesiamelakukannya dengan mengikuti pelatihan dimana informasi maupun pengetahuan yang didapat tersebut diolah ke dalam bentuk laporan untuk disampaikan kepada pimpinan. Menurut Rodin (2018) internalisasi juga dapat terjadi melalui kegiatan yang pustakawan ikuti di luar lembaga melalui forum maupun dari dalam lembaga tersebut seperti seminar dan sebagainya. Karena pada dasarnya, dalam kegiatan tersebut, tentunya pustakawan memperoleh pengetahuan-pengetahuan baru.

Media yang digunakan dalam penyampaian informasi antar pustakawan maupun antara pustakawan dengan pimpinan adalah melalui interaksi atau komunikasi dalam hal ini melalui 
diskusi maupun dituangkan ke dalam bentuk tercetak seperti laporan. Kedua cara tersebut merupakan media penyampaian informasi yang digunakan oleh pustakawan dengan pimpinan. Hal yang dilakukan dalam penyampaian informasi antar pustakawan yaitu dengan selalu melakukan sharing melalui diskusi mengenai kegiatan kepustakawanan sehari-hari yang dilakukan dalam hal pengolahan maupun kendala yang dirasakan. Hal tersebut dilakukan untuk meminimalisir kendala yang dialami oleh kedua pustakawan maupun bertukar informasi atau pengetahuan mengenai bidang yang dikerjakan. Selain itu, hal yang dilakukan dalam penyampaian informasi antara pustakawan dengan pimpinan diantaranya melalui diskusi serta laporan kegiatan yang diikuti oleh pustakawan. Dalam interaksi antara pustakawan dengan pimpinan, membahas mengenai permasalahan perpustakaan, kendala yang dirasakan oleh pustakawan, kegiatan yang akan dilaksanakan maupun kegiatan yang telah diikuti oleh pustakawan. Hal tersebut dilakukan untuk mengevaluasi kinerja yang telah dilakukan sebelumnya dan untuk mengembangkan serta memajukan perpustakaan melalui inovasi yang didapat dari kegiatan yang telah diikuti oleh pustakawan.

Hambatan yang terdapat dalam proses transfer pengetahuan di Perpustakaan Kemenkumham diantaranya adalah dalam penyampaian maupun penyerapan informasi yang menyebabkan miskomunikasi maupun kesalahan dalam mengartikan informasi, kurangnya sumber daya manusia sehingga pustakawan masih terfokus pada kegiatan teknis seperti pengolahan. Meskipun begitu, hambatan dalam kurangnya sumber daya manusia ini dapat diatasi dengan interaksi yang terjalin oleh pustakawan dalam setiap pekerjaannya. Selain itu, penyerapan anggaran yang belum sempurna juga menjadi faktor penghambat para pustakawan untuk mengembangkan dan menyalurkan pengetahuannya melalui kegiatan pelatihan maupun workshop.

\section{E. KESIMPULAN DAN SARAN}

Transfer pengetahuan di Perpustakaan Kementerian Hukum dan Hak Asasi Manusia Republik Indonesia terdiri dari proses sosialisasi, proses eksternalisasi, proses kombinasi, dan proses internalisasi. Sosialisasi seringnya terjadi melalui interaksi dalam kegiatan kepustakawanan sehari-hari dalam hal pengolahan, membahas permasalahan di perpustakaan, maupun sharing dalam diskusi mengenai kegiatan yang akan dilaksanakan, kegiatan yang diikuti oleh pustakawan, maupun mendiskusikan terkait perpustakaan. Hal tersebut dilakukan untuk 
meminimalisir kemungkinan kendala yang akan timbul dikemudian hari serta menjadi bahan evaluasi bagi instansi. Eksternalisasi dilakukan dengan menuangkan pemikiran ke dalam makalah, serta merekam informasi yang didapat dari kegiatan di luar lembaga ke dalam catatan lalu dituangkan kembali ke dalam bentuk laporan dan disampaikan dalam diskusi sebagai bentuk penyebaran pengetahuan. Bentuk laporan tersebut tidak hanya sebagai laporan kegiatan dinas, tetapi dalam hal ini bentuk laporan juga merupakan bentuk pengetahuan dari kegiatan pustakawan lainnya.

Kombinasi dilakukan melalui aktivitas mengumpulkan, mentransfer atau menyebarkan, dan mengolah informasi maupun pengetahuan yang diperoleh dari tahap eksternalisasi ke dalam laporan tahunan. Dokumen tersebut disebarkan maupun didiskusikan kembali oleh pustakawan kepada pimpinan dalam sebuah diskusi sebagai sebuah evaluasi. Untuk proses internalisasi, hal ini belum optimal dilakukan. Ini dikarenakan kegiatan pustakawan yang masih berfokus pada kegiatan pengolahan perpustakaan. Namun, dari kegiatan-kegiatan yang diikuti oleh pustakawan di luar instansi maupun melalui dokumen-dokumen dari kegiatan tersebut dapat menjadi pengetahuan baru dan menambah pengetahuan baru bagi individu maupun organisasi. Hambatan yang dialami terletak pada sumber daya manusia dimana sumber daya manusia di Perpustakaan Kemenkumham masih sangat terbatas dan penyerapan anggaran untuk perpustakaan yang belum maksimal untuk keperluan perpustakaan. Sehingga dengan kedua hambatan tersebut tentunya menghambat para pustakawan untuk mengeksplorasi ide untuk mengembangkan perpustakaan.

\section{DAFTAR PUSTAKA}

Chen, D. Y. T., Chu, S. K. W., \& Xu, S. Q. (2012). How do libraries use social networking sites to interact with users. Proceedings of the ASIST Annual Meeting, 49(1). https://doi.org/10.1002/meet.14504901085

Glassop, L. L. (2002). The organizational benefits of teams. Human Relation, 55(2), 225-249.

Indriartiningtias, R., \& Mafrufah, I. (2012). Analisis Pengaruh Transfer Pengetahuan Terhadap Kelompok Tani Pengolah Salak Di Bangkalan. Prosiding Seminas, 1(2).

Lee, H. W. (2005). Knowledge management and the role of libraries. Proceedings of the 3rd China-US Library Conference, 22-25.

Nonaka, I. \& Takeuchi, H. (1995). The knowledge-creating company: how Japanese companies create the dynamics of innovation. Oxford: Oxford University Press.

Nurbaiti, A. Z. N. (2013). Implementasi knowledge sharing terhadap kinerja pustakawan di Kantor Perpustakaan, Arsip Dan Dokumentasi Kabupaten Sukoharjo. Skripsi. Semarang: UNDIP.

Parindra, R. L. G. (2018). Pengelolaan informasi dan dokumentasi "knowledge sharing pada tbm warung pasinaon" bergas. Nusantara-Journal of Information and Library Studies, 1(1), 66-80. 
Rahardjo, M. (2017). Studi kasus dalam penelitian kualitatif: konsep dan prosedurnya. Journal of Personality and Social Psychology (Vol. 1). https://doi.org/10.1111/j.1469-7610.2010.02280.x

Rodin, R, Kismiyati, T. \& Margono, T. (2015). Implementasi knowledge sharing sebagai upaya peningkatan efetifitas keprofesionalan pustakawan (Studi kasus di Perpustakaan STAIN Curup. Media Pustakawan, 23(5), 123-139.

Rodin, R. (2018, Desember 17-20). Pustakawan Ahli Madya. (B. A. Ragili, Pewawancara)

Sangkala. (2007). Knowledge Management: Suatu Pengantar Memahami Bagaimana Organisasi Mengelola Pengetahuan Sehingga Menjadi Organisasi Yang Unggul. Jakarta: PT. Rajagrafindo Persada.

Syam, A. M. (2017). Penerapan "knowledge sharing" di perpustakaan. JIPI (Jurnal Ilmu Perpustakaan dan Informasi), 2(2), 261-272.

Sugiyono. (2015). Memahami penelitian kualitatif. Bandung: Alfabeta.

Tobing, L. P. (2007). Knowledge management: konsep, arsitektur, dan implementasi. Yogyakarta: Graha Ilmu.

Yin, R. K. (2014). Studi kasus desain dan metode. Jakarta: Rajagrafindo Persada. 